\title{
Insecticidal activities of Russia coriander oils and these constituents against Sitophilus oryzae and Sitophilus zeamais
}

\author{
Seon-A Choi ${ }^{1} \cdot$ Hoi-Seon Lee $^{1}$ \\ 러시아산 고수종자에서 추출한 정유성분 및 구성성분의 쌀바구미 및 \\ 어리쌀바구미에 대한 살충효과
}

최선아 ${ }^{1} \cdot$ 이회선 $^{1}$

Received: 21 July 2018 / Accepted: 30 July 2018 / Published Online: 30 September 2018

(C) The Korean Society for Applied Biological Chemistry 2018

\begin{abstract}
Essential oils of coriander (Coriandrum sativum L.) seeds were extracted by three extraction methods, steam distillation extraction (SDE), hexane extraction (HE) and supercritical extraction (SE), to compare their insecticidal activities against Sitophilus oryzae and S. zeamais. Although the essential oil extracted by HE and SE did not show insecticidal activities, the essential oil extracted by SDE showed the highest insecticidal activities against $S$. oryzae and $S$. zeamais. The chemical compositions of the essential oil extracted by SDE were analyzed by GC-MS. The most abundant compounds were linalool (59.92\%), camphor (7.94\%), linalool oxide (7.70\%), p-cymene (7.44\%), $\alpha$ pinene (6.44\%), limonene (3.29\%) and geranyl acetate (3.19\%). Camphor and linalool as major constituents showed the highest insecticidal activities against $S$. oryzae and $S$. zeamais whereas other constituents did not show insecticidal activities. As a result, the essential oil extracted by SDE, camphor and linalool showed a potential for development as insecticide against the storage pests.
\end{abstract}

Keywords Camphor · Coriandrum sativum · Insecticide Sitophilus oryzae $\cdot$ Sitophilus zeamais

Hoi-Seon Lee $(\bowtie)$

E-mail: hoiseon@jbnu.ac.kr

${ }^{1}$ Department of Bioenvironmental Chemistry, Chonbuk National University, Jeonju 54896, Republic of Korea

This is an Open Access article distributed under the terms of the Creative Commons Attribution Non-Commercial License (http://creativecommons. org/licenses/by-nc/3.0/) which permits unrestricted non-commercial use, distribution, and reproduction in any medium, provided the original work is properly cited.

\section{서 론}

저곡해충은 곡물의 생산, 유통 및 저장 과정에서 유입되어 곡 물의 양적 또는 질적 손실을 발생시키며[1,2], 이들은 연간 곡 물생산량 중에 약 $30 \%$ 의 경제적 손실을 일으키고 있다[3]. 가 장 대표적인 저곡해충은 거짓쌀도둑거저리(Tribolium castaneum), 긴털가루응애(Tyrophagus putrescentiae), 보리나방(Sitotroga cerealella), 쌀바구미(Sitophilus oryzae), 어리쌀바구미(Sitophilus zeamais) 및 화랑곡나방(Plodia interpunctella)이 있다. 이러한 저곡해충 6 종 중에 쌀바구미와 어리쌀바구미는 온대 및 열대 지역에서 흔히 발견되는 대표적 저곡해충이며, 이들은 저장 중 인 쌀눈에 구멍을 내어 그 안에 산란하기 때문에 육안으로 판 단하기 어려울 뿐만 아니라 방제가 까다로운 실정이다.

저곡해충을 방제하기 위한 방법에는 저온 및 고온처리, controlled atmosphere (CA) 처리 등의 물리적 방법과 합성살충 제를 이용한 화학적 방법이 있다. 물리적 방법은 넓은 범위에 서 다양한 종류의 저곡해충을 효과적으로 방제할 수 있지만, 장 비 도입이 어렵고 시설 유지비용이 많이 소모되어 단점으로 작 용된다. 또한 저곡해충의 감광성을 이용한 LED 해충트랩이 연 구된 바 있으나[4], 현재까지는 보편화가 되지 않은 상황이다. 이러한 물리적 방법의 한계로 인해서 저곡해충 방제에는 주로 화학적 방법이 이용되어 왔으며, 살충제는 메틸브로마이드가 주 로 사용되었다. 메틸브로마이드는 각종 해충뿐만 아니라 잡초 및 토양병원균까지 방제하는 효과가 있어서 농업환경에 폭넓게 사용되었으나 잔류성이 강하고 인체에 대한 발암성이 확인되었 을 뿐만 아니라 오존층 파괴 원인물질 중의 하나로 밝혀져서 2015년부터 생산/사용이 금지되었다[5]. 이런 이유로 메틸브로마 이드를 대체할 제재로서 식물에서 유래한 추출물 및 구성성분 이 주목받고 있다. 식물은 외부의 공격으로부터 보호하기 위한 
방어기작으로서 이차 대사산물을 생산하는데[6], 이들은 곤충의 유인 또는 기피를 유도하며, 병원균 및 해충에 대한 살균 및 살 충활성을 일으키기도 한다[7]. 본 연구에서 사용된 고수 (Coriandrum sativum L.)는 널리 알려진 약용식물이며 소화불량, 식욕감퇴, 경련 및 불면증의 치료제로 사용되어 왔을 뿐만 아 니라 향신료 및 화장품의 원료로 사용되어 왔다[8,9]. 고수의 생 리활성 연구로는 Chaudhry와 Tariq[10]에 의해 176종 박테리아 에 대한 항균활성이 보고된 바 있으며, Khani와 Rahdari[11]에 의해 거짓쌀도둑거저리 및 녹두 딱정벌레(Callosobruchus maculatus)에 대한 살충활성이 보고된 바 있다. 이처럼 다양한 생리활성을 갖고 있는 고수 정유에 대한 연구가 오랜 시간 동 안 이루어져 왔으나, 추출 방법에 따른 고수 정유의 생리활성 및 저곡해충에 대한 살충활성 연구는 미흡한 실정이다. 따라서 본 연구에서는 살충활성에 대한 잠재성을 지닌 고수 종자를 수 증기증류, 용매 및 초임계 추출법으로 추출한 각각의 정유와 정 유 구성성분들의 쌀바구미 및 어리쌀바구미에 대한 접촉독성 및 훈증독성 생물검정법을 이용하여 저곡해충에 대한 살충제로서 의 잠재력을 확인하고자 하였다.

\section{재료 및 방법}

\section{정유 추출}

고수 종자는 전라북도 전주에 소재한 한약재 시장에서 러시아 산으로 구입하였고, 구입한 고수 종자는 증류수로 세척하여 건 조한 후 분쇄기를 이용하여 마쇄하였다. 고수 종자에 대한 정 유 추출은 전라남도 장흥에 소재한 전남생물산업진흥원 천연자 원연구센터에서 이루어졌으며, 수증기증류, 용매 및 초임계 추 출법으로 정유를 수집하였다. 수증기증류 추출은 정유 추출기 (EM-250, Micro)를 이용하였으며, 추출 용매로서는 헥산 300 $\mathrm{mL}$ 를 사용하였다. 증류수 $1,500 \mathrm{~mL}$ 에 마쇄한 고수 종자를 추 출조에 넣고 $100{ }^{\circ} \mathrm{C}$ 로 가열하여 증기를 발생시켰고, 증기와 함 께 기화된 정유는 냉각기로 이동하여 수용기에서 응집되었다. 4 시간 이후에 수용기에 응집된 것 중에 정유가 함유된 헥산 용 매층을 수집하여 감압농축을 통해 용매를 휘발시켜 정유를 수 집하였다. 용매추출은 헥산을 용매로 사용하여 수행하였다. 마 쇄한 고수 종자와 헥산을 $1: 10$ 의 비율로 하여 $5,000 \mathrm{~mL}$ 삼각 플라스크에 넣고, 48 시간 동안 진탕기를 이용해 진탕하였다. 이 후 감압여과를 통해 불순물을 걸러낸 후 감압농축을 수행하여 용매를 휘발시키고 정유를 수집하였다. 초임계추출은 초임계 유 체 추출장비(5L-1000BAR-PILOT PLANT)를 이용하여 수행하 였다. 추출조와 분리조의 압력은 모두 $400 \mathrm{bar}$ 로 하였고, 추출 조, 분리조 및 냉각기의 온도는 각각 50,40 및 $-2{ }^{\circ} \mathrm{C}$ 로 하였 으며, $\mathrm{CO}_{2}$ 유량은 $60 \mathrm{~mL} / \mathrm{min}$ 으로 설정하였다. 이와 같은 조건 으로 120 분간 수행하여 정유성분을 수집하였다. 추출된 각각의 정유는 시료병에 넣어 밀봉한 후 $4{ }^{\circ} \mathrm{C}$ 에서 냉장보관 하였다.

\section{시험약제}

Camphor, p-cymene, geranyl acetate 및 linalool oxide는 Sigma-Aldrich (St Louis, MO, USA)에서 구입하였으며, limonene, linalool 및 $\alpha$-pinene은 Tokyo Chemical Industry (TCI, Tokyo, Japan)에서 구입하였다.

\section{GC-MS}

러시아산 고수 종자에서 수증기 증류 추출법으로 추출한 정유 는 GC (Agilient HP-6890)-MS (Agilent 5973IV)를 이용하여 분석하였다. 컬럼은 $\mathrm{DB}-5$ 컬럼 $(0.25 \mathrm{~mm} \times 30 \mathrm{~mL} \times 0.25 \mu)$ 을 이 용하였고, 가스는 헬륨을 이용하여 유량을 $0.8 \mathrm{~mL} / \mathrm{min}$ 으로 설 정하였다. Ion source 및 주입구 온도는 각각 220 및 $210^{\circ} \mathrm{C}$ 로 하였고, 오븐 온도는 $20-220{ }^{\circ} \mathrm{C}\left(2{ }^{\circ} \mathrm{C} / \mathrm{min}\right)$ 로 하여서 15 분간 수 행하였다. 검출기는 $220^{\circ} \mathrm{C}$ 에서 $70 \mathrm{eV}$ 의 이온화 조건에서 수행 하였다.

\section{저곡해충}

쌀바구미와 어리쌀바구미 성충은 전북대학교 응용식물생화학실 의 해충사육실에서 5 년동안 살충제에 전혀 노출되지 않은 감수 성 계통으로 누대 사육한 것을 사용하였다. 사육조건은 최적조 건에 따라 온도 $25 \pm 1{ }^{\circ} \mathrm{C}$, 상대습도 $68 \pm 4 \%$, 광주기 $9 \mathrm{~L}: 15 \mathrm{D}$ 의 조건에서 가로 $30 \mathrm{~cm} \times$ 세로 $30 \mathrm{~cm} \times$ 높이 $30 \mathrm{~cm}$ 의 플라스틱 사 육상자에 쌀을 먹이로 공급하여 사육하였다.

\section{접촉독성법}

시료는 메탄올을 용매로 하여 $105-421 \mu \mathrm{g} / \mathrm{cm}^{2}$ 의 농도로 희석하 였고, 지름 $55 \mathrm{~mm}$ 의 filter paper에 각 시료를 $100 \mu \mathrm{L}$ 씩 처리한 후 10 분간 음건하였다. 그리고 건조한 filter paper를 지름 60 $\mathrm{mm}$ 의 petri dish 바닥에 놓고 쌀바구미와 어리쌀바구미 성충을 20 마리씩 접종한 후 para film으로 밀봉하였다. 처리된 petri dish는 온도 $25 \pm 1{ }^{\circ} \mathrm{C}$, 상대습도 $68 \pm 4 \%$, 광주기 $9 \mathrm{~L}: 15 \mathrm{D}$ 조건의 항온항습실에 보관하여 24시간 후에 살충활성을 확인하였다.

\section{훈중독성법}

시료는 메탄올을 용매로 하여 $75-303 \mu \mathrm{g} / \mathrm{cm}^{3}$ 의 농도로 희석하 였고, 지름 $25 \mathrm{~mm}$ 의 filter paper에 각 시료를 $100 \mu \mathrm{L}$ 씩 처리한 후 10 분간 음건하였다. 쌀바구미와 어리쌀바구미 성충은 각각 20 마리씩 시료병(지름 $34 \mathrm{~mm} \times$ 높이 $115 \mathrm{~mm}$ )에 접종하였으며, 천 으로 입구를 막은 후 시료병의 뚜껑에 건조한 filter paper를 놓 고 닫았다. 처리된 시료병은 온도 $25 \pm 1{ }^{\circ} \mathrm{C}$, 상대습도 $68 \pm 4 \%$, 광주기 9L:15D 조건으로 맞춘 항온항습실에 보관하여 24시간 후에 살충활성을 확인하였다. 접촉독성 및 훈증독성에 의한 치 사 판정은 각각 성충에 침으로 충분히 자극을 주었을 때 미동 도 하지 않는 것을 사망한 것으로 판단하였다.

\section{통계분석}

각 시험은 3 반복으로 수행하였으며, 본 시험을 통해 얻어진 결 과는 SPSS 통계 프로그램(ver.12.0)의 probit analysis을 통해 반 수치사량 $\left(\mathrm{LD}_{50}\right)$, slope 및 $\chi^{2}$ (chi-square value)으로 나타내었다.

\section{결과 및 고찰}

고수 종자에 대한 수증기증류, 용매 및 초임계 추출법을 이용 한 정유의 추출 수율은 시료 양 $(\mathrm{g})$ 과 추출된 정유 양 $(\mathrm{g})$ 의 중량 비로 계산하여 그 결과를 Table 1에 나타내었다. 수증기증류, 용 매 및 초임계 추출법은 $200 \mathrm{~g}$ 의 시료에서 각각 $0.58,4.44$ 및 $6.88 \mathrm{~mL}$ 정유가 추출되었으며, 수율은 각각 $0.29,2.22$ 및 
Table 1 Yield of Russia Coriandrum sativum oils by three extract methods

\begin{tabular}{ccccc}
\hline \hline Plants & Extract method & Dried weight $(\mathrm{g})$ & Extract time $(\mathrm{h})$ & Yield amount $(\mathrm{mL})$ \\
\hline & Steam & 200 & 4 & 0.58 \\
Coriandrum sativum & Solvent & 200 & 53 & 4.44 \\
(Seed) & Supercritical & 200 & 8 & 2.22 \\
& & 3.44 & 6.88 \\
\hline
\end{tabular}

Table 2 Insecticidal activities of Russia Coriandrum sativum oils by three extract methods against Sitophilus spp.

\begin{tabular}{|c|c|c|c|c|c|}
\hline Bioassay & Extract method & Insects & $\mathrm{LD}_{50}(95 \% \mathrm{CI})$ & Slope \pm SE & $\chi^{2}(\mathrm{df}, p)$ \\
\hline \multirow{6}{*}{$\begin{array}{l}\text { Contact } \\
\left(\mu \mathrm{g} / \mathrm{cm}^{2}\right)\end{array}$} & \multirow{2}{*}{ Steam } & S. oryzae & $107.56(89.06-130.62)$ & $3.15 \pm 0.45$ & $2.718(5,0.743)$ \\
\hline & & S. zeamais & $108.40(88.27-134.61)$ & $3.12 \pm 0.49$ & $3.527(4,0.474)$ \\
\hline & \multirow{2}{*}{ Solvent } & S. oryzae & $>421.00$ & $\mathrm{a}$ & \\
\hline & & S. zeamais & $>421.00$ & & \\
\hline & \multirow{2}{*}{ Supercritical } & S. oryzae & $>421.00$ & & \\
\hline & & S. zeamais & $>421.00$ & & \\
\hline \multirow{6}{*}{$\begin{array}{l}\text { Fumigant } \\
\left(\mu \mathrm{g} / \mathrm{cm}^{3}\right)\end{array}$} & \multirow{2}{*}{ Steam } & S. oryzae & $79.88(62.70-99.38)$ & $3.16 \pm 0.46$ & $2.277(4,0.685)$ \\
\hline & & S. zeamais & $80.29(62.46-99.64)$ & $3.04 \pm 0.55$ & $2.717(4,0.606)$ \\
\hline & \multirow{2}{*}{ Solvent } & S. oryzae & $>303.00$ & & \\
\hline & & S. zeamais & $>303.00$ & & \\
\hline & \multirow{2}{*}{ Supercritical } & S. oryzae & $>303.00$ & & \\
\hline & & S. zeamais & $>303.00$ & & \\
\hline
\end{tabular}

${ }^{\text {a No activity }}$

$3.44 \%$ 로 측정되었다.

고수 종자의 수증기증류, 용매 및 초임계 추출법에 의하여 추 출한 정유의 쌀바구미 및 어리쌀바구미 성충에 대한 살충활성 을 확인하였다(Table 2). 쌀바구미 및 어리쌀바구미 성충에 대 한 접촉독성은 $\mathrm{LD}_{50}$ 값이 각각 107.56 및 $108.40 \mu \mathrm{g} / \mathrm{cm}^{2}$ 로 나 타났으며, 훈증독성은 각각 79.88 및 $80.29 \mu \mathrm{g} / \mathrm{cm}^{3}$ 로 나타났다. 그러나 용매추출 및 초임계 추출법으로 추출한 정유에서는 쌀 바구미 및 어리쌀바구미 성충에 대하여 어떠한 살충활성도 나 타나지 않았다. 이를 통해 각 추출법에 따른 정유성분의 살충 활성은 추출법에 따라 상이한 결과를 나타냄을 확인할 수 있었 다. 고수종자의 수증기증류 추출법으로 추출한 정유성분에 대한 어리쌀도둑거저리와 녹두 딱정벌레에 대한 살충활성이 밝혀진 바 있는데[11], 본 연구에서도 고수의 수증기증류 추출법으로 추 출한 정유가 우수한 훈증독성을 나타냄을 확인하였다.

본 연구에 사용된 쌀바구미 및 어리쌀바구미에 대한 살충활 성을 나타낸 수증기증류 추출법으로 추출한 정유의 구성성분을 확인하기 위해 GC-MS 분석을 수행하여 그 결과를 Table 3에 나타내었다. 정유에 함유된 구성성분은 총 19 종이 검출되었으 며, 그 중 함량이 가장 많은 성분은 linalool로 전체 정유의 $59.92 \%$ 의 함량을 나타내었다. 그 다음으로 camphor $(7.94 \%)$, linalool oxide $(7.70 \%), p$-cymene $(7.44 \%), \alpha$-pinene $(6.44 \%)$, limonene (3.29\%), geranyl acetate $(3.19 \%)$ 의 순으로 함량 차 이를 나타내었다. 일반적으로 고수 종자의 주성분은 linalool로 알려져 있으며[12-15], 본 연구에서 분석한 결과는 전에 진행된 연구결과와 유사한 결과를 나타내었다. 그러나 camphor는 많은 연구에서 그 함량이 적은 것으로 나타남에도 불구하고[9,12-15], 본 연구에서 사용한 수증기증류 추출법에 의한 고수 정유에서 는 두 번째로 많은 비율을 차지하여 기존 연구와 상이한 결과 를 나타내었다. 또한 Lee 등[16]의 연구에서는 고수종자의 수증 기증류 추출법에 의한 정유의 GC-MS 분석을 수행한 결과,
Table 3 GC-MS analysis of Russia Coriandrum sativum oils by steam distillation method

\begin{tabular}{|c|c|c|c|}
\hline No & Compounds & $\mathrm{RT}^{\mathrm{a}}$ & Composition (\%) \\
\hline 1 & $\alpha$-Pinene & 4.950 & 6.44 \\
\hline 2 & Camphene & 5.235 & 1.09 \\
\hline 3 & $\beta$-Pinene & 5.750 & 0.34 \\
\hline 4 & $\beta$-Myrcene & 5.927 & 0.20 \\
\hline 5 & p-Cymene & 6.605 & 7.44 \\
\hline 6 & Limonene & 6.690 & 3.29 \\
\hline 7 & $\gamma$-Vinyl- $\gamma$-valerolactone & 6.868 & 0.16 \\
\hline 8 & trans-Linalool oxide & 7.493 & 7.70 \\
\hline 9 & Linalool & 8.018 & 59.92 \\
\hline 10 & $\begin{array}{l}\text { 1,2-Dimethyl-3-(1-methylethenyl) } \\
\text { cyclopentanol }\end{array}$ & 8.457 & 0.14 \\
\hline 11 & Camphor & 8.862 & 7.94 \\
\hline 12 & Terpinene-4-ol & 9.395 & 0.11 \\
\hline 13 & 2,6-Dimethyl-3,7-octadiene-2,6-diol & 9.491 & 0.57 \\
\hline 14 & $\alpha$-Terpineol & 9.606 & 0.81 \\
\hline 15 & Geranyl formate & 11.313 & 0.13 \\
\hline 16 & Geranyl acetate & 12.504 & 3.19 \\
\hline 17 & Davanone & 17.002 & 0.15 \\
\hline 18 & Geranial & 17.658 & 0.11 \\
\hline \multirow[t]{9}{*}{19} & Farnesol & 19.019 & 0.24 \\
\hline & Major Grouped Compounds & & \\
\hline & Monoterpene alcohol & & 61.79 \\
\hline & Monoterpene ester & & 3.30 \\
\hline & Monoterpene ether & & 7.99 \\
\hline & Monoterpene ketone & & 7.94 \\
\hline & Monoterpene hydrocarbon & & 18.80 \\
\hline & Sesquiterpene ketone & & 0.15 \\
\hline & Total $(\%)$ & & 99.97 \\
\hline
\end{tabular}

${ }^{\text {aThe retention time }}$ 
linalool이 $66.80 \%$ 로서 본 연구 결과보다 높은 함량을 나타낸 반면 camphor는 $6.46 \%$ 로 본 연구결과보다 낮은 함량을 나타내 었다. 이러한 차이는 식물체의 유전적 요인, 수확 시기, 재배지 의 토양 상태 및 기후 변화 등의 요인에 의한 것으로 판단된다 $[17,18]$.

$\mathrm{GC}-\mathrm{MS}$ 분석 결과에서 $3 \%$ 이상 검출된 성분을 선발하여 쌀 바구미 및 어리쌀바구미 성충에 대한 살충활성을 확인하였다 (Table 4). 쌀바구미 및 어리쌀바구미 성충에 대한 접촉독성은 camphor의 $\mathrm{LD}_{50}$ 값이 각각 201.64 및 $205.38 \mu \mathrm{g} / \mathrm{cm}^{2}$ 로 가장 우수한 살충활성을 나타내었으며, 그 다음으로 linalool이 282.96 및 $338.25 \mu \mathrm{g} / \mathrm{cm}^{2}$ 의 살충활성을 나타내었다. 나머지 5종 구성성 분에서는 쌀바구미 및 어리쌀바구미 성충에 대한 살충활성을 확 인할 수 없었다. 접촉독성법애 의한 쌀바구미 및 어리쌀바구미 성충에 대한 camphor의 $\mathrm{LD}_{50}$ 값이 각각 148.52 및 $152.18 \mu \mathrm{g}$ / $\mathrm{cm}^{3}$ 로 가장 우수한 살충활성을 나타내었으며, 그 다음으로 linalool이 152.83 및 $211.18 \mu \mathrm{g} / \mathrm{cm}^{3}$ 의 활성을 나타내었다. 나머 지 5 종 구성성분에서는 접촉독성과 마찬가지로 쌀바구미 및 어 리쌀바구미 성충에 대한 살충활성을 확인할 수 없었다. 위 결 과를 통해서 쌀바구미 및 어리쌀바구미 성충은 camphor와 linalool에 대해 우수한 살충활성을 나타냈으며, 정유와 단일 성 분의 살충효과검정 결과 접촉독성보다 훈증독성이 우수하였기
때문에 이들의 작용기작은 훈증작용에 의한 것으로 알 수 있었 다. Chen 등[19]은 녹나무(Cinnamomum camphora) 정유와 구 성성분에 대하여 권연벌레(Lasioderma serricorne)에 대한 살충 활성을 검정한 결과, 정유 구성성분 중에 camphor가 linalool보 다 뛰어난 살충활성을 보인다고 보고한 바 있다. 또한 접촉독 성보다 훈증독성에서 더욱 우수한 살충활성을 나타내어서 본 연 구결과와 유사한 연구결과를 보였다. 본 연구를 통하여 고수종 자에서 수증기증류 추출법으로 추출한 정유성분, camphor 및 linalool은 저곡해충에 대한 훈증제로서 잠재력이 있는 것으로 생각된다. 또한 고수종자의 정유는 단일구성성분보다 쌀바구미 및 어리쌀바구미 성충에 대한 접촉독성과 훈증독성이 모두 뛰 어남을 확인할 수 있었는데, 이러한 연구결과는 단일성분보다 그들을 일정 비율로 혼합하였을 때 더욱 우수한 살충활성을 보 이는 상승 효과(synergistic activity) 일 것으로 추정된다. 본 연 구에서 활성본체로 밝혀진 camphor는 borneol, 1,8-cineol 및 $\alpha$-pinene 등의 물질들과 상승효과를 일으킨다고 밝혀진 바 있 다[20-22].

위 결과를 종합하면, 본 연구를 통해 고수종자의 수증기증류 추출법으로 추출한 정유에서 쌀바구미 및 어리쌀바구미에 대한 접촉독성 및 훈증독성을 확인할 수 있었으며, $\mathrm{GC}-\mathrm{MS}$ 를 통한 성분분석과 각각 구성성분의 살충활성 검정을 통해 camphor와

Table 4 Insecticidal activities of constituents derived from Russia Coriandrum sativum oils against Sitophilus spp.

\begin{tabular}{|c|c|c|c|c|c|c|}
\hline Bioassay & Compounds & Insects & $\mathrm{LD}_{50}$ & $95 \% \mathrm{CI}$ & Slope \pm SE & $\chi^{2}(\mathrm{df}, p)$ \\
\hline \multirow{14}{*}{$\begin{array}{l}\text { Contact } \\
\left(\mu \mathrm{g} / \mathrm{cm}^{2}\right)\end{array}$} & Camphor & S. oryzae & 201.64 & $168.29-243.76$ & $3.52 \pm 0.56$ & $5.469(4,0.242)$ \\
\hline & & S. zeamais & 205.38 & $173.69-245.83$ & $3.82 \pm 0.62$ & $6.667(4,0.155)$ \\
\hline & $p$-Cymene & S. oryzae & $>421.00$ & $-{ }^{a}$ & - & - \\
\hline & & S. zeamais & $>421.00$ & - & - & - \\
\hline & Geranyl acetate & S. oryzae & $>421.00$ & - & - & - \\
\hline & & S. zeamais & $>421.00$ & - & - & - \\
\hline & Limonene & S. oryzae & $>421.00$ & - & - & - \\
\hline & & S. zeamais & $>421.00$ & - & - & - \\
\hline & Linalool & S. oryzae & 282.96 & $246.43-323.85$ & $4.87 \pm 0.78$ & $3.044(4,0.550)$ \\
\hline & & S. zeamais & 338.25 & $287.16-392.24$ & $4.18 \pm 0.71$ & $6.607(4,0.158)$ \\
\hline & Linalool oxide & S. oryzae & $>421.00$ & - & - & - \\
\hline & & S. zeamais & $>421.00$ & - & - & - \\
\hline & $\alpha$-Pinene & S. oryzae & $>421.00$ & - & - & - \\
\hline & & S. zeamais & $>421.00$ & - & - & - \\
\hline \multirow{14}{*}{$\begin{array}{l}\text { Fumigant } \\
\left(\mu \mathrm{g} / \mathrm{cm}^{3}\right)\end{array}$} & Camphor & S. oryzae & 148.52 & $93.35-191.51$ & $6.22 \pm 1.06$ & $8.152(4,0.086)$ \\
\hline & & S. zeamais & 152.18 & $124.16-181.27$ & $3.65 \pm 0.60$ & $4.137(4,0.388)$ \\
\hline & $p$-Cymene & S. oryzae & $>303.00$ & - & - & - \\
\hline & & S. zeamais & $>303.00$ & - & - & - \\
\hline & Geranyl acetate & S. oryzae & $>303.00$ & - & - & - \\
\hline & & S. zeamais & $>303.00$ & - & - & - \\
\hline & Limonene & S. oryzae & $>303.00$ & - & - & - \\
\hline & & S. zeamais & $>303.00$ & - & - & - \\
\hline & Linalool & S. oryzae & 152.83 & $116.30-199.79$ & $2.34 \pm 0.37$ & $5.691(4,0.223)$ \\
\hline & & S. zeamais & 211.18 & $183.63-246.29$ & $4.56 \pm 0.71$ & $4.198(4,0.380)$ \\
\hline & Linalool oxide & S. oryzae & $>303.00$ & - & - & - \\
\hline & & S. zeamais & $>303.00$ & - & - & - \\
\hline & $\alpha$-Pinene & S. oryzae & $>303.00$ & - & - & - \\
\hline & & S. zeamais & $>303.00$ & - & - & - \\
\hline
\end{tabular}

${ }^{\text {a No activity }}$ 
linalool이 고수종자의 정유에서 살충활성을 갖는 활성본체임을 규명하였다.

\section{초 록}

쌀바구미 및 어리쌀바구미에 대한 고수 종자에서 추출한 정유 의 살충활성을 비교하기 위하여 3가지 추출법(수증기증류, 용매 및 초임계 추출법)을 통해 정유를 추출하였다. 용매 및 초임계 추출법으로 추출한 정유는 쌀바구미 및 어리쌀바구미에 대해 살 충효과를 나타내지 않은 반면에 수증기증류 추출법으로 추출한 정유는 쌀바구미 및 어리쌀바구미에 대하여 살충효과를 나타내 었다. 고수종자의 수증기증류 추출법으로 추출한 정유를 $\mathrm{GC}-$ $\mathrm{MS}$ 를 통해 분석한 결과 linalool $(59.92 \%)$ 이 가장 많은 함량을 나타내었으며, 그 다음으로 camphor $(7.94 \%)$, linalool oxide (7.70\%), p-cymene (7.44\%), $\alpha$-pinene (6.44\%), limonene (3.29\%), geranyl acetate $(3.19 \%)$ 의 순으로 함량 차이를 나타내었다. 이 들 중 camphor와 linalool은 쌀바구미 및 어리쌀바구미에 대해 가장 우수한 살충활성을 나타내었으며, 나머지 성분들은 살충활 성을 나타내지 않았다. 본 연구결과는 고수종자의 수증기증류 추출법에 의한 정유와 구성성분인 camphor 및 linalool이 저곡 해충에 대한 살충제로서의 잠재력을 지니고 있는 것을 보여준다.

Keywords Camphor - Coriandrum sativum - Insecticide · Linalool - Sitophilus oryzae - Sitophilus zeamais

감사의 글 본 연구과제는 농촌진흥청 공동연구사업(PJ011983012018)의 지 원으로 수행되었습니다.

\section{References}

1. Padin S (2002) Grain loss caused by Tribolium castaneum, Sitophilus oryzae and Acanthoscelides obtectus in stored durum wheat and beans treated with Beauveria bassiana. J Stored Prod Res 38: 69-74

2. Reed CR, Hagstrum DW, Flinn PW, Allen RF (2003) Wheat in Bins and Discharge Spouts, and Grain Residues on Floors of Empty Bins in Concrete Grain Elevators as Habitats for Stored-Grain Beetles and Their Natural Enemies. J Econ Entomol 96: 996-1004

3. Haubruge E, Arnaud L, Mignon J (1997) The impact of sperm precedence in malathion resistance transmission in populations of the red flour beetle Tribolium castaneum (Herbst) (Coleoptera: Tenebrionidae). J Stored Prod Res 33: 143-146

4. Park JH, Lee HS (2017) Phototactic behavioral response of agricultural insects and stored-product insects to light-emitting diodes (LEDs). Appl Biol Chem 60: 137-144

5. Ristaino JB, Thomas W (1997) Agriculture, methyl bromide, and the ozone hole: can we fill the gaps? PLANT DIS 81: 964-977

6. Rattan RS (2010) Mechanism of action of insecticidal secondary metabolites of plant origin. Crop Prot 29: 913-920

7. Koul O, Walia S, Dhaliwal GS (2008) Essential oils as green pesticides: potential and constraints. Biopestic Int 4: 63-84

8. Emamghoreishi M, Khasaki M, Aazam MF (2005) Coriandrum sativum: evaluation of its anxiolytic effect in the elevated plus-maze. J Ethnopharmacol 96: 365-370

9. Msaada K, Hosni K, Taarit MB, Chahed T, Kchouk ME, Marzouk B (2007) Changes on essential oil composition of coriander (Coriandrum sativum L.) fruits during three stages of maturity. Food Chem 102: 11311134

10. Chaudhry NM, Tariq P (2006) Bactericidal activity of black pepper, bay leaf, aniseed and coriander against oral isolates. Pak J Pharm Sci 19: 214-218

11. Khani A, Rahdari T (2012) Chemical composition and insecticidal activity of essential oil from Coriandrum sativum seeds against Tribolium confusum and Callosobruchus maculatus. ISRN Pharm 2012: $1-5$

12. Bhuiyan MNI, Begum J, Sultana M (2009) Chemical composition of leaf and seed essential oil of Coriandrum sativum L. from Bangladesh. Bangladesh J Pharmacol 4: 150-153

13. Eikani MH, Golmohammad F, Rowshanzamir S (2007) Subcritical water extraction of essential oils from coriander seeds (Coriandrum sativum L.). J Food Eng 80: 735-740

14. Shahwar MK, El-Ghorab AH, Anjum FM, Butt MS, Hussain S, Nadeem M (2012) Characterization of coriander (Coriandrum sativum L.) seeds and leaves: volatile and non-volatile extracts. Int J Food Prop 15: 736747

15. Zoubiri S, Baaliouamer A (2010) Essential oil composition of Coriandrum sativum seed cultivated in Algeria as food grains protectant. Food Chem 122: 1226-1228

16. Lee MJ, Lee SE, Kang MS, Park B, Lee SG, Lee HS (2018) Acaricidal and insecticidal properties of Coriandrum sativum oils and their major constituents extracted by three different methods against stored product pests. Appl. Biol. Chem. doi: 10.1007/s13765-018-0379-Z

17. Telci I, Toncer OG, Sahbaz N (2006) Yield, essential oil content and composition of Coriandrum sativum varieties (var. vulgare Alef and var. microcarpum DC.) grown in two different locations. J Essent Oil Res 18: 189-193

18. Maddonni GA, Urricariet S, Ghersa CM, Lavado RS (1999) Assessing soil quality in the Rolling Pampa, using soil properties and maize characteristics. Agron J 91: 280-287

19. Chen HP, Yang K, You CX, Lei N, Sun RQ, Geng ZF, Ma P, Cai Q, Du SS, Deng ZW (2014) Chemical constituents and insecticidal activities of the essential oil of Cinnamomum camphora leaves against Lasioderma serricorne. J Chem 43: 1019-1026

20. Tak JH, Jovel E, Isman MB (2016) Comparative and synergistic activity of Rosmarinus officinalis L. essential oil constituents against the larvae and an ovarian cell line of the cabbage looper, Trichoplusia $n i$ (Lepidoptera: Noctuidae). Pest Manag Sci 72: 474-480

21. Pavela R (2014) Acute, synergistic and antagonistic effects of some aromatic compounds on the Spodoptera littoralis Boisd. (Lep., Noctuidae) larvae. Ind Crop Prod 60: 247-258

22. Lee MJ, Park JH, Lee HS (2018) Acaricidal toxicities and synergistic activities of Salvia lavandulifolia oil constituents against synanthropic mites. Pest Manag Sci. doi: 10.1002/ps.4924 